\title{
Critical Success Factors of TQM Implementation in Vietnamese Supporting Industries
}

\author{
Tran Van TRANG ${ }^{1}$, Quang Hung DO²
}

Received: April 18, 2020 Revised: May 03, 2020 Accepted: June 07, 2020

\begin{abstract}
The objective of this study is to prioritize the Total Quality Management (TQM) factors based on fuzzy Analytical Hierarchy Process (AHP) method in Vietnamese supporting industries. Through an in-depth literature review, eight criteria were identified. These criteria were then divided into 32 sub-criteria. The fuzzy AHP is used to determine the percent weightings of eight categories of performance criteria that were identified via a review of the quality-management literature. These criteria include management commitment, role of the quality department, training and education, continuous improvement, quality policies, quality data and reporting, communication to improve quality, and customer satisfaction orientation. An empirical analysis of the criteria of each stage using the fuzzy AHP methodology and the expert opinion of quality management are used to evaluate the percent weightings of the criteria and sub-criteria that are synonymous with TQM implementation. The results showed that management commitment is the most critical factor; among sub-criteria, supports and responsibilities of top management is the most important. The study also identified the rank order of critical success factors of TQM. The findings suggest a generic hierarchy model for organizations to prioritize the critical factors and formulate strategies for implementing TQM in supporting industries, as well as other industries in Vietnam.
\end{abstract}

Keywords: Total Quality Management, Vietnam, Supporting Industry, Fuzzy AHP, Decision Making Process

JEL Classification Code: L16, L60, C69

\section{Introduction}

The Total Quality Management (TQM) in operational environment has been getting much attention from practitioners, managers, and researchers since its significant contribution to business performance, cost, customer satisfaction, customer loyalty, and profitability (Talib, Rahman, \& Qureshi, 2011). In the implementation of TQM, it is essential that the organizations identify major factors, which should be given special attention for ensuring

${ }^{1}$ First Author. Senior Lecturer, Faculty of Business Administration, Thuongmai University, Vietnam. Email: tranvotrang@tmu.edu.vn ${ }^{2}$ Corresponding Author. Senior Lecturer, Faculty of Information Technology, University of Transport Technology, Vietnam [Postal Address: No 54, Trieu Khuc, Thanh Xuan Nam, Hanoi 100000, Vietnam] Email: hungdq@utt.edu.vn

(c) Copyright: The Author(s)

This is an Open Access article distributed under the terms of the Creative Commons Attribution Non-Commercial License (http://Creativecommons.org/licenses/by-nc/4.0/) which permits unrestricted noncommercial use, distribution, and reproduction in any medium, provided the original work is properly cited. successful implementation of the TQM program and strategy. The supporting industries have made a significant contribution to the economic grow in Vietnam. The supporting industries focus on the supply of raw materials, spare parts, and components to manufacturing industries (Rahman \& Saima, 2018), thus becoming a substantial determinant of the industrialization process of Vietnam. In order to improve productivity and quality of Vietnam's supporting industries, TQM is an efficient tool in the improvement of quality and business performance.

Analytical Hierarchy Process (AHP) is a method to solve complex decision-making problems with a variety of selection criteria and a wide range of decision-makers. Basically, AHP uses information or expert opinions to determine the relative importance or contribution of attributes and to synthesize an optimal selection solution. Therefore, the AHP method can be introduced into the TQM process to solve the existing problems in the implementation of TQM (Wang \& $\mathrm{Li}$, 2010). Although AHP is usually strong enough to explain and describe expert knowledge, it cannot adequately and fully reflect human behavior and thought. Thus, fuzzy AHP, 
a fuzzy extension of AHP, was developed to solve the fuzzy decomposition problem. In the fuzzy AHP process, pairwise comparisons in matrices are fuzzy numbers. Therefore, decision makers can assign priorities in the form of natural language expressions on the importance of each criterion. Thus, fuzzy logic provides a systematic basis for handling unclear or unclear situations. For mentioned reasons, the fuzzy AHP method is a suitable approach to identify key factors in a clear and scientific way.

The application of AHP and fuzzy AHP to TQM has been widely used in various sectors and regions. Tseng, Lin, Chiu, and Chen (2008) evaluated TQM strategic factors based on Fuzzy AHP to identify the critical success factors in environmental uncertainty. The application case in the study is the printed circuit board (PCB) industry in Taiwan. Ulle and Kumar (2015) made an extensive literature review on key performance indicators (KPI) of Total Quality Management (TQM) and supported by various other philosophies of TQM. Then, a model was developed that includes KPI of TQM and quality improvement to investigate their influence on the performance of the Small and Medium Enterprise (SME) industries. Talib at al. (2011) identified a set of 17 TQM practices in service industry; then, these were grouped into three categories. After that, the priority of the TQM practices was ranked by experts from the service industries and academia using the AHP method. A research on TQM practice in real-estate industry using AHP was conducted in India (Sarathy, 2013). The results showed that the Employee's Involvement is most important to TQM practice in India. A study was conducted to investigate the extent to which the criteria of TQM have been attained due to the implementation of the ISO 9001:2000 Standard (Lewis, Pun, \& Lalla, 2005)weaknesses are highlighted to which scarce resources could be parsimoniously allocated. Design/ methodology/approach - The analytic hierarchy process (AHP in SMEs.

A model based on the AHP method was developed to acquire and analyze industry practitioners' opinions among the stages and related sub-criteria that determine the success of TQM implementation. The study suggested that the company should focus on systems deployment and continual improvement. Using the AHP method, Khanam, Siddiqui, and Talib (2015) suggested a hierarchy model for ICT industry to prioritize the enablers and resources as well as to improve the TQM and IT performance in the ICT industry. Wang and Li (2010) developed a TQM performance evaluation indices system based on the AHP method. Koilakuntla, Patyal, Modgil, and Ekkuluri (2012) proposed a several factors are to be considered for effective deployment of TQM in an organization. Then, the authors developed organization-specific factors and factor ratings by considering business specific key performance indicators (KPIs) along with weighted ratings by the use of
AHP. Salgado, da Silva, da Silva, and Pereira Mello (2015) presented the application of the AHP to prioritize practices of TQM for Small and Medium-sized Enterprises in Brazil. It was found that strategic factors are considered of greater importance for TQM. The operational factors are considered of lesser importance when compared to the tactical and strategic factors, but the customer focus sub criterion is considered a major (Kim \& Kim, 2020; Pham, Nguyen, Tu, Pham, \& Le, 2019). Chin, Pun, Xu, and Chan (2002) used the AHP approach to prioritize the relative importance of four critical factors and sixteen sub-factors among state-owned enterprises and foreign joint ventures in China. The study's findings showed that these enterprises would stress the soft TQM factors of organizing, and culture and people rather than the hard TQM factors of the systems, techniques and measurement, and feedback. Top management commitment, leadership, education and training are among the most important sub-factors.

The objective of this study is to determine the order of TQM critical success factors in the context of Vietnam's supporting industries by fuzzy AHP method. The paper is organized as follows. After introduction, the literature review on fuzzy AHP is provided in Section 2. Section 3 presents the proposed framework for prioritizing TQM factors based on fuzzy AHP; Section 4 is devoted to the hierarchy of TQM critical success factors. Section 5 presents the application of the proposed framework related to Vietnam's supporting industries. Finally, Section 6 concludes the study.

\section{Fuzzy Analytic Hierarchy Process (FAHP)}

The AHP decision-making process uses pairwise comparison judgments and matrix algebra to identify and estimate the relative importance of criteria and alternatives. The method queries relevant experts using a nine-point scale. AHP has the power to solve complex decision problems. However, ambiguous problems can limit the power of pure AHP. Fuzzy AHP, an extension of the AHP model, has been applied to fuzzy decision-making problems. In fuzzy AHP, by using fuzzy arithmetic operation laws, the weights of evaluative elements are determined. There are several fuzzy AHP methods reported in the literature. The first work of fuzzy AHP was proposed by van Laarhoven and Pedrycz (1983), which compared fuzzy ratios described by triangular fuzzy numbers. They applied the logarithmic least square method to derive fuzzy weights and scores. Buckley (1985) and Buckley, Feuring, and Hayashi (2001) used comparison ratios based on trapezoidal fuzzy numbers to deal with the imprecision in a decision maker's evaluation. They extended Saaty's AHP and used the geometric mean method to obtain fuzzy weights and scores. Chang $(1992,1996)$ proposed a new extent analysis approach based on triangular fuzzy numbers for pairwise comparison. 
Buyukozkam and Feyziog̃lu (2004) made a comparison of the fuzzy AHP methods which have differences in their theoretical structures. In the work, they pointed out the advantages as well as disadvantages of each method with several points of view. In this paper, the method proposed by Buckley is employed. The calculation steps of local weights of criteria at a given level are as follows:

A matrix $\overparen{A}$ is constructed according to fuzzy pairwise comparison.

$$
\widetilde{A}=\left[\begin{array}{cccc}
1 & \tilde{a}_{12} & \ldots & \tilde{a}_{1 n} \\
\tilde{a}_{12} & 1 & \ldots & \tilde{a}_{2 n} \\
\ldots & \ldots & \ldots & \ldots \\
\tilde{a}_{n 1} & \tilde{a}_{n 2} & \ldots & 1
\end{array}\right]
$$

where $\tilde{a}_{i j}=\left(l_{i j}, m_{i j}, u_{i j}\right)$ is the fuzzy comparison value of criterion i to criterion $\mathrm{j}$

The fuzzy weights of each criterion are calculated

$$
\begin{array}{r}
\tilde{r}_{i}=\left(\tilde{a}_{i 1} \otimes \tilde{a}_{i 2} \otimes \ldots . \otimes \tilde{a}_{i n}\right)^{1 / n} \text { for } \mathrm{i}=1,2, \ldots, \mathrm{n} \\
\tilde{w}_{i}=\frac{\tilde{r}_{i}}{\tilde{r}_{1} \otimes \tilde{r}_{2} \otimes \ldots . \otimes \tilde{r}_{n}} \text { for } \mathrm{i}=1,2, \ldots, \mathrm{n}
\end{array}
$$

where $\tilde{r}_{i}$ is the geometric mean of fuzzy comparison value of criterion i to each criterion, and $\widetilde{w}_{i}$ is the fuzzy weight of the ith criterion.

The fuzzy weight vector $\widetilde{W}$ is constructed as:

$$
\widetilde{W}=\left(\tilde{w}_{1}, \tilde{w}_{2}, \ldots, \tilde{w}_{n}\right)^{T}
$$

\section{Prioritizing TQM Factors based on Fuzzy AHP}

\subsection{Developing a Hierarchical Structure}

The hierarchical structure is constructed by combining all the criteria, sub-criteria specific to the research problem. Based on the identified criteria and attributes, the hierarchical structure for evaluation is obtained. In the system, the objective is in the first level, criteria and attributes are in successive levels. This step also dissects the problem into elements according to their common characteristics. Regarding the number of elements, Miller (1956) stated that most decision makers cannot simultaneously handle more than seven to nine factors when making a decision.

\subsection{Selecting Decision-Makers}

A group of decision-makers is formed. The members of the group are experts who have experiences about the research issue. The decision-makers are required to provide the relative importance of each criterion and attribute.

\subsection{Determining the Linguistic Variables and Fuzzy Conversion Scale}

The decision-makers make pairwise comparisons of the importance or preference between each pair of criteria. The comparison of one criterion over another can be done with the help of questionnaires and it is in the form of linguistic variables. A linguistic variable is a variable whose values are words or sentences in a natural or artificial language (Zadeh, 1975). In this paper, TFNs are used to represent subjective pairwise comparisons of decision-makers, namely "just equal", "equally important", "weakly more important", "strongly more important", "very strongly more important" and "absolutely more important". The triangular fuzzy conversion scales and linguistic scales, which is proposed by Kahraman, Ertay, and Büyüközkan (2006), is used to convert such linguistic values into fuzzy scales is demonstrated in Figure 1 and Table 1.

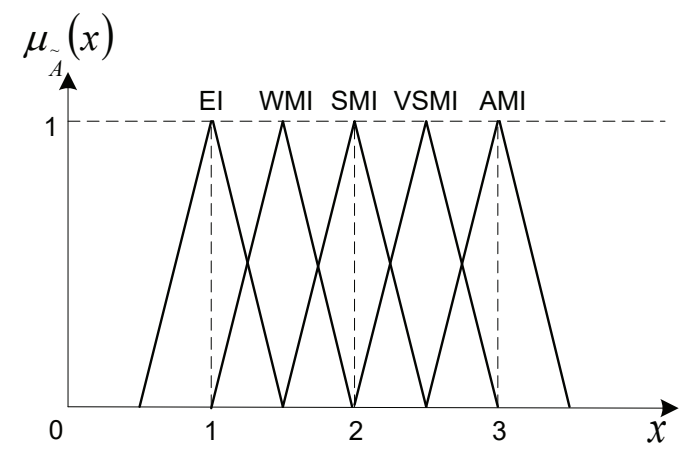

Figure 1: Linguistic scale for relative importance

Table 1: Linguistic scales and fuzzy scales for importance

\begin{tabular}{|l|c|c|}
\hline \multicolumn{1}{|c|}{$\begin{array}{c}\text { Linguistic scale } \\
\text { for importance }\end{array}$} & $\begin{array}{c}\text { Triangular } \\
\text { fuzzy scale }\end{array}$ & $\begin{array}{c}\text { Triangular fuzzy } \\
\text { reciprocal scale }\end{array}$ \\
\hline Just equal & $(1,1,1)$ & $(1,1,1)$ \\
\hline $\begin{array}{l}\text { Equally important } \\
(\text { El) }\end{array}$ & $(1 / 2,1,3 / 2)$ & $(2 / 3,1,2)$ \\
\hline $\begin{array}{l}\text { Weakly more } \\
\text { important (WMI) }\end{array}$ & $(1,3 / 2,2)$ & $(1 / 2,2 / 3,1)$ \\
\hline $\begin{array}{l}\text { Strongly more } \\
\text { important (SMI) }\end{array}$ & $(3 / 2,2,5 / 2)$ & $(2 / 5,1 / 2,2 / 3)$ \\
\hline $\begin{array}{l}\text { Very strongly more } \\
\text { important (VSMI) }\end{array}$ & $(2,5 / 2,3)$ & $(1 / 3,2 / 5,1 / 2)$ \\
\hline $\begin{array}{l}\text { Absolutely more } \\
\text { important (AMI) }\end{array}$ & $(5 / 2,3,7 / 2)$ & $(2 / 7,1 / 3,2 / 5)$ \\
\hline
\end{tabular}




\subsection{Establishing Comparison Matrices}

Suppose that a problem at one level with $\mathrm{n}$ criteria, where the relative importance of criterion $\mathrm{i}$ to $\mathrm{j}$ is represented by triangular fuzzy numbers $\tilde{a}_{i j}=($ lij, mij,uij) For example, one decision-maker considers criterion $\mathrm{i}$ is strongly more important as compared with the criterion $\mathrm{j}$; he may set $\tilde{a}_{i j}=(3 / 2,2,5 / 2)$. If criterion $\mathrm{j}$ is thought to be strongly more important than criterion $i$, the pairwise comparison between $\mathrm{i}$ and $\mathrm{j}$ could be presented by $a_{i j}=(2 / 5,1 / 2,2 / 3)$.

As in the traditional AHP, the comparison matrix $\widetilde{A}=\left\{\tilde{a}_{i j}\right\}$ can be constructed, such that

$$
\widetilde{A}=\left[\begin{array}{cccc}
1 & \tilde{a}_{12} & \ldots & \tilde{a}_{1 n} \\
\tilde{a}_{21} & 1 & \ldots & \tilde{a}_{2 n} \\
\ldots & \ldots & \ldots & \ldots \\
\tilde{a}_{n 1} & \tilde{a}_{n 2} & \ldots & 1
\end{array}\right]=\left[\begin{array}{cccc}
1 & \tilde{a}_{12} & \ldots & \tilde{a}_{1 n} \\
1 / \tilde{a}_{21} & 1 & \ldots & \tilde{a}_{2 n} \\
\ldots & \ldots & \ldots & \ldots \\
1 / \tilde{a}_{1 n} & 1 / \tilde{a}_{2 n} & \ldots & 1
\end{array}\right]
$$

\subsection{Calculating the Consistency Index and Consistency Ratio of Comparison Matrix}

To assure a certain quality level of a decision, the consistency of an evaluation has to be analyzed. Karayalcin (1982) proposed a consistency index to measure consistency. This index can be used to indicate how consistent the pairwise comparison matrices are. To investigate the consistency, the fuzzy comparison matrices need to be converted into crisp matrices (Chen \& Lee, 2011). The fuzzy mean and spread method proposed by Lee and Li (1988) is utilized to defuzzify the fuzzy numbers. This method ranks fuzzy numbers according to the probabilities of fuzzy events. Assume that $\tilde{a}_{i j}=\left(l_{i j}, m_{i j}, u_{i j}\right)$ is a TFN with uniform distribution. Its mean $x\left(\tilde{a}_{i j}\right)$ is calculated as

$$
x\left(\tilde{a}_{i j}\right)=\left(l_{i j}+m_{i j}+u_{i j}\right) / 3
$$

After all the elements in the comparison matrix are converted from triangular fuzzy numbers to crisp numbers. The consistence index, CI, for a comparison matrix can be computed with the use of the following equation.

$$
C I=\frac{\lambda_{\max }-n}{n-1}
$$

where, $\lambda_{\max }$ is the largest eigenvalue of the comparison matrix, $\mathrm{n}$ is the dimension of the matrix.

Table 2: Random index (RI) of random matrices

\begin{tabular}{|c|c|c|c|c|c|c|c|}
\hline $\mathrm{n}$ & 3 & 4 & 5 & 6 & 7 & 8 & 9 \\
\hline $\mathrm{RI}(\mathrm{n})$ & 0.58 & 0.9 & 1.12 & 1.24 & 1.32 & 1.41 & 1.45 \\
\hline
\end{tabular}

The consistency ratio is defined as a ratio between the consistency of a given evaluation matrix and consistency of a random matrix.

$$
C R=\frac{C I}{R I(n)}
$$

where, $R I(n)$ is a random index (Golden, 1989) that depends on $\mathrm{n}$, as shown in Table 2.

If the consistency ratio (CR) of a comparison matrix is equal or less than 0.1 , it can be acceptable. When the $\mathrm{CR}$ is unacceptable, the decision-maker is encouraged to repeat the pairwise comparisons. In this step, the MATLAB package can be employed to calculate the eigenvalues of all comparison matrices.

\subsection{Constructing the Group Judgment Matrix}

Since each individual judgment matrix represents the opinion of one decision maker, aggregation is necessary to achieve a group consensus of decision-makers. In the conventional AHP, there are two basic approaches for aggregating the individual preferences into a group preference, namely, aggregation of individual judgments (AIJ) and aggregation of individual priorities (AIP) (Forman \& Peniwati, 1998). The concepts and ideas employed in the conventional AHP can be also utilized in the fuzzy AHP. In the AIJ approach, the group judgment matrix is obtained from the individual judgment matrices. This means that the group judgment matrix is considered as the judgment matrix of a "new individual" and the priorities of this individual are derived as a group solution. However, in the AIP approach, the group members act individually. Specifically, from the individual judgment matrices, we obtain the individual priorities, and from these, the group priorities are derived. The choice of whether to use AIJ or AIP depends on the degree of complexity of required fuzzy arithmetic operations. In this paper, we use the AIJ approach for aggregation of group decisions.

Suppose that a group of $\mathrm{K}$ decision-makers involved in the research. They make pairwise comparison of $n$ criteria. As a result of the pairwise comparisons, we get a set of $\mathrm{K}$ matrices $\tilde{A}_{k}=\left\{\tilde{a}_{i j k}\right\}$, where $\tilde{a}_{i j k}=($ lijk,mijk,uijk $)$ represents a relative importance of criterion $i$ to $j$, as assessed by the expert $\mathrm{k}$. The triangular fuzzy numbers in the group judgment matrix can be obtained by using the following equation (Büyüközkan \& Feyziog̃lu, 2004):

$$
\begin{aligned}
& l_{i j}=\min _{k=1,2, \ldots K}\left(l_{i j k}\right) \\
& u_{i j}=\min _{k=1,2, \ldots K}\left(u_{i j k}\right)
\end{aligned} \quad m_{i j}=\sqrt[K]{\prod_{k=1}^{K} m_{i j k}}
$$




\subsection{Calculating the Local Weights of Criteria and Sub-Criteria}

The fuzzy AHP method proposed by Buckley is then employed to calculate the weights of criteria and sub-criteria.

\subsection{Calculating the Global Weights of the Sub- Criteria}

Global sub-criterion weights are computed by multiplying the local weight of the criteria with the local weight of the criterion to which it belongs.

\section{The Hierarchy of TQM Success Factors}

Many studies can be found in the literature, which investigate identification TQM critical success factors.
Based on a systematic literature review, Hietschold, Reinhardt, and Gurtner (2014) identified 145 papers and Aquilani, Silvestri, Ruggieri, and Gatti (2017a) found 103 articles related to this topic. Previous research has developed a plethora of measurement instruments and researchers do not agree on certain factors or on one single measurement instrument (Hietschold et al., 2014). According to Aquilani et al. (2017a), there are three different clusters of papers: identification of CSFs papers which show that customer focus has gained importance in recent times; implementation of CSFs papers which highlight that a general or shared model or scale to successfully implement total quality management (TQM) does not yet exist; and impact on performance of CSFs paper which show that few studies have considered the relationship between TQM and the issues of both marketing and performance.

Table 3: Common CSFs extracted from literature review

\begin{tabular}{|c|c|c|}
\hline Authors & Purpose and Method & Results \\
\hline $\begin{array}{l}\text { (Saraph, } \\
\text { Benson, \& } \\
\text { Schroeder, } \\
\text { 1989) }\end{array}$ & $\begin{array}{l}\text { - Develop an instrument for studying critical } \\
\text { success factors of quality management in } \\
\text { Minneapolis, USA. } \\
\text { - Empirical study, } n=162 \text { general managers and } \\
\text { quality managers }\end{array}$ & $\begin{array}{l}\text { Eight factors (with } 66 \text { elements) } \\
\text { 1. Top management leadership } \\
\text { 2. Role of the quality department } \\
\text { 3. Training } \\
\text { 4. Product design } \\
\text { 5. Supplier quality management } \\
\text { 6. Process management } \\
\text { 7. Quality data reporting } \\
\text { 8. Employee relations }\end{array}$ \\
\hline $\begin{array}{l}\text { (Black \& Porter, } \\
\text { 1996) }\end{array}$ & $\begin{array}{l}\text { - To identify critical success factors of TQM in } \\
\text { the membership organizations of European } \\
\text { Foundation for Quality Management (EFQM) } \\
\text { - Empirical study, } n=200 \text { managers }\end{array}$ & $\begin{array}{l}\text { Ten factors (with } 32 \text { elements) } \\
\text { 1. People and customer management } \\
\text { 2. Supplier partnerships } \\
\text { 3. Communication of improvement information } \\
\text { 4. Customer satisfaction orientation } \\
\text { 5. External interface management } \\
\text { 6. Strategic quality management } \\
\text { 7. Teamwork structures for improvement } \\
\text { 8. Operational quality planning } \\
\text { 9. Quality improvement measurement systems } \\
\text { 10. Corporate quality culture }\end{array}$ \\
\hline $\begin{array}{l}\text { (Joseph, } \\
\text { Rajendran, \& } \\
\text { Kamalanabhan, } \\
\text { 1999) }\end{array}$ & $\begin{array}{l}\text { - Identify TQM success factors in Indian } \\
\text { organization } \\
\text { - Empirical study, } n=50 \text { respondents }\end{array}$ & $\begin{array}{l}\text { Ten factors (106 elements) } \\
\text { 1. Organizational commitment } \\
\text { 2. Human resources management } \\
\text { 3. Supplier integration } \\
\text { 4. Quality policy } \\
\text { 5. Product design } \\
\text { 6. Role of quality department } \\
\text { 7. Quality information systems } \\
\text { 8. Technology utilization } \\
\text { 9. Operating procedures } \\
\text { 10. Training }\end{array}$ \\
\hline
\end{tabular}




\begin{tabular}{|c|c|c|}
\hline Authors & Purpose and Method & Results \\
\hline $\begin{array}{l}\text { (Antony, Leung, } \\
\text { Knowles, \& } \\
\text { Gosh, 2002) }\end{array}$ & $\begin{array}{l}\text { - Identify TQM success factors in Hong Kong } \\
\text { industries } \\
\text { - Empirical study, n= } 66 \text { questionnaires from } 32 \\
\text { companies }\end{array}$ & $\begin{array}{l}\text { Seven factors (with } 38 \text { items) } \\
\text { 1. Training and education } \\
\text { 2. Quality data and reporting } \\
\text { 3. Management commitment } \\
\text { 4. Customer satisfaction orientation } \\
\text { 5. Role of the quality department } \\
\text { 6. Communication to improve quality } \\
\text { 7. Continuous improvement }\end{array}$ \\
\hline $\begin{array}{l}\text { (Ismail } \\
\text { Salaheldin, } \\
\text { 2009) }\end{array}$ & $\begin{array}{l}\text { - Identify TQM success factors and their impact } \\
\text { on the performance of SMEs in the Qatari } \\
\text { industrial sector } \\
\text { - Empirical study, } n=139 \text { questionnaires }\end{array}$ & $\begin{array}{l}\text { Three group of factors (with } 24 \text { elements) } \\
\text { 1. Strategic factors } \\
\text { 2. Tactical factors } \\
\text { 3. Operational factors }\end{array}$ \\
\hline $\begin{array}{l}\text { (Hietschold et } \\
\text { al., 2014) }\end{array}$ & $\begin{array}{l}\text { - Identify dimensions of critical success factors } \\
\text { and classify them into a general framework } \\
\text { - Literature review, } n=145 \text { papers }\end{array}$ & $\begin{array}{l}\text { 11 factors (CSFs within each dimension not } \\
\text { mentioned, given as example) } \\
\text { 1. HRM/recognition/ teamwork } \\
\text { 2. Top management commitment and leadership } \\
\text { 3. Process management } \\
\text { 4. Customer focus and satisfaction } \\
\text { 5. Supplier partnership } \\
\text { 6. Training and learning } \\
\text { 7. Information/analysis/data } \\
\text { 8. Strategic quality planning } \\
\text { 9. Culture and communication } \\
\text { 10. Benchmarking } \\
\text { 11. Social and environmental responsibility }\end{array}$ \\
\hline $\begin{array}{l}\text { (Aquilani et al., } \\
2017 a)\end{array}$ & $\begin{array}{l}\text { - Review all critical factors of TQM and } \\
\text { identify new research avenues and different } \\
\text { approaches to implementing TQM } \\
\text { - Literature review, } n=103 \text { papers }\end{array}$ & $\begin{array}{l}\text { 10 factors (sub-factors not mentioned) } \\
\text { 1. Leadership/top management commitment/role of } \\
\text { top management } \\
\text { 2. Customer focus/satisfaction } \\
\text { 3. Training and education } \\
\text { 4. Measurement or metric systems/data information } \\
\text { and analysis/quality data and reporting } \\
\text { 5. Supplier collaboration/management/ supplier } \\
\text { quality (management) } \\
\text { 6. Process quality management } \\
\text { 7. Continuous improvement } \\
\text { 8. TQM as a strategic issue/planning/role of quality } \\
\text { department } \\
\text { 9. Employee commitment and attitude/ involvement } \\
\text { 10. Organizational culture/quality culture/ } \\
\text { organizational climate/learning }\end{array}$ \\
\hline
\end{tabular}

A detailed literature review is performed to identify the CSFs of TQM implementation. Some important research directly related to TQM success factors in industry are presented in Table 3. After identifying these most common CSFs as in Table 3, we conducted a focus group consisting of six quality managers from six supporting enterprises to identify the factors most appropriate for TQM implementation in Vietnamese supporting industry. Finally, through a literature review and discussion with experts, eight TQM criteria were identified and further divided into 32 sub-criteria.

\subsection{Top Management Commitment (C1)}

Top management is the highest-ranking executives (with titles such as chairman, chief executive officer, managing director, president, executive directors, etc.) responsible for the entire enterprise. "TQM must start at the top, where serious obsession and commitment to quality and leadership need to be demonstrated" (Oakland, 2011).

Commitment of top management has been considered as one of the most important factors impacting the success 
for implementation of TQM practice in an organization. Without proper guidelines from the top management, the implementation of TQM will be much difficult. Employees throughout the organization need to impress upper management in order to advance up the corporate ladder. When top management states its commitment to a given strategy, this provides subordinates with salient clues for impressing upper management (Chowdhury, Paul, \& Das, 2007).

\subsection{Role of the Quality Department (C2)}

The main task of a quality department is to ensure profit margins by reducing inefficiencies, operations errors, and product defects. Moreover, improving capability and capacity of operations through new methods, tools or skills must be considered. This factor includes five sub-criteria.

\subsection{Training and Education (C3)}

Training and education have become an important issue due to the rapid growth of technological innovation and development. Training in quality concepts and tools is a precondition for employee involvement and empowerment (Kanji \& Asher, 1993). "TQM training" is considered "a key to successful implementation of TQM along the dimensions of cost reduction and profit increase" (Kassicieh \& Yourstone, 1998). Employees equipped with knowledge and abilities can make constructive contributions to quality (Rao, Solis, \& Raghunathan, 1999). There are four sub-criteria chosen for this factor according to our focus group discussion.

\subsection{Continuous Improvement (C4)}

According to Hackman and Wageman (Hackman \& Wageman, 1995), a core principle of TQM is learning and continuous improvement. The long-term health of an enterprise depends on treating quality improvement as a never-ending quest. Opportunities to develop better methods for carrying out work always exist, and a commitment to continuous improvement ensures that people will never stop learning about the work they do. Continuous improvement deal not only with improving results, but more importantly with improving capabilities to produce better results in the future. This factor includes four sub-criteria.

\subsection{Quality Policies (C5)}

The quality policy is a guide for all in the organization as to how they should provide products and services to the customers. A quality policy must incorporate an organization's vision or mission statement and core values.

\subsection{Quality Data and Reporting (C6)}

TQM calls for the use of systematically collected data at every point in a problem-solving cycle-from determining high-priority problems, through analyzing their causes, to selecting and testing solutions (Hackman \& Wageman, 1995). The collection of appropriate data is essential to monitor the current quality status. Enterprises cannot evaluate the quality of products and services correctly, if they cannot measure the status before and after improvement activities (Jayaram, Ahire, \& Dreyfus, 2010). The availability of information in an organization is needed for decision-making process and transparency.

\subsection{Communication to Improve Quality (C7)}

The effectiveness of the management is facilitated by communication. Effective communication holds together

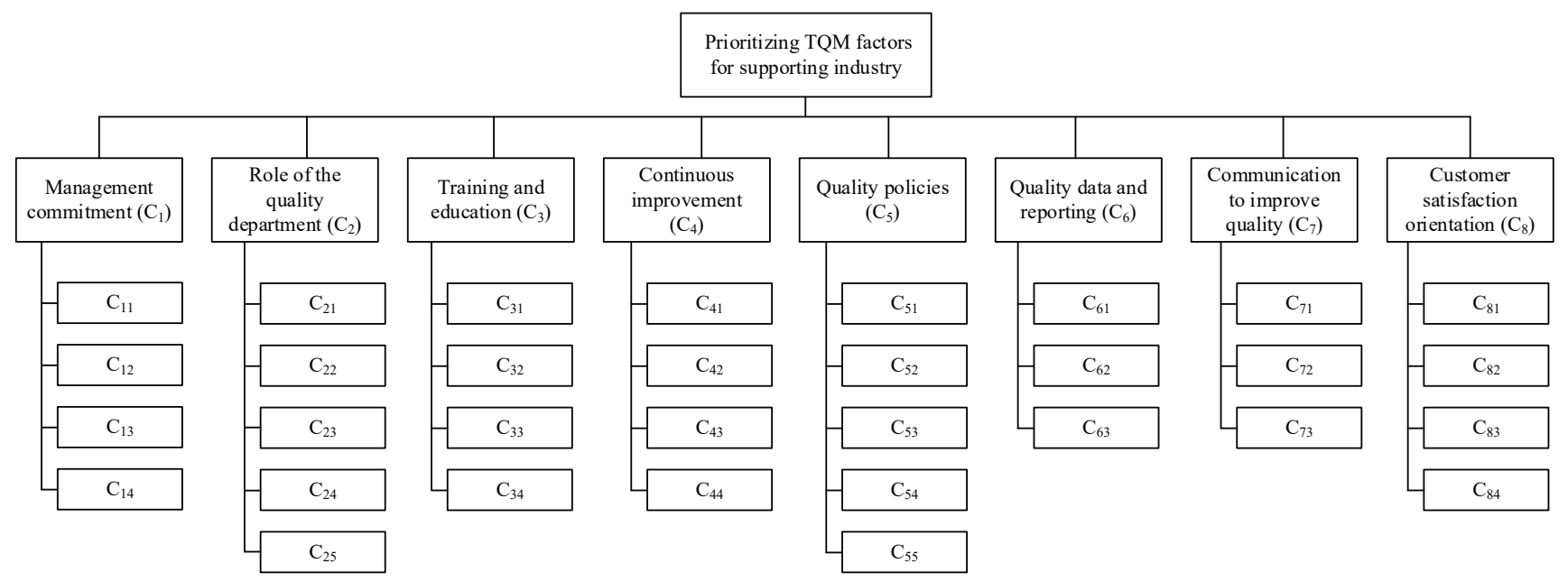

Figure 2: The hierarchy of TQM factors for Vietnamese supporting industry 
the pieces of the total quality process and is important for the success of the quality initiative (Baidoun, 2003). When management explains quality goals and policies to employees, they encourage their commitment to the TQM program (Welikala \& Sohal, 2008).

\subsection{Customer Satisfaction Orientation (C8)}

According to Mehra, Huffman, Austin, and Sirias (2001), customer focus receives particular attention as a CSF, because by definition TQM is a customer-orientated practice. Customer orientation relates to the goal of identifying and meeting current and emerging customer needs (Nair, 2006). Consumer opinions can enhance the product and service quality and therefore should be included in each stage of the product development process (Das, Paul, \& Swierczek, 2008). Based on literature review of identification of CSFs papers, Aquilani, Silvestri, Ruggieri, and Gatti (2017b) show that customer focus has gained importance in recent times. In our study, this factor includes 3 sub-criteria. In all, Figure 2 presents all criteria.

\section{Application of the Proposed Framework}

Our study is related to prioritizing TQM factors based on fuzzy AHP in the context of Vietnam's supporting industries. To acquire the weights of criteria and sub-criteria, a group of $20 \mathrm{TQM}$ experts including academicians, quality consultants and industry experts in quality was established. The questionnaires were provided to get their viewpoints. Pairwise comparisons, which were derived from their assessments on the relative importance of one criterion over another, were used to form comparison matrices of each expert. The geometric mean method was then applied to get the representative comparison matrix of the group. The representative comparison matrix of the group acquired when making pairwise comparisons of the criteria.

Among these experts' answers, five questionnaires contained inconsistent answers. These inconsistent questionnaires were sent back to the experts to be filled out again, whereupon two experts refused to revise and correct their responses. Consequently, their answers were excluded from the data analysis. Therefore, the result of this study is based on the responses of 18 experts. These 18 respondents are from five academicians, eight TQM consultants and five top level management executives.

\section{Results and Discussions}

Table 4 shows the local and global weights of criteria and sub-criteria in the TQM hierarchy in the context of Vietnam's supporting industries. The table provides us the relative ranking of the criteria and sub-criteria. Regarding the criteria, Management commitment is the most important TQM factor, followed by Role of the quality department factor; the third place is Training and education, and finally Communication to improve quality is ranked 8 th.

To assess the overall relative importance of sub-criteria, the global weight for each criterion needs to be determined. The global weight of sub-criterion indicates the importance of each sub-criterion to the TQM practice. The global weight of each sub-criterion in the hierarchical structure is computed by multiplying the fraction index with the index of the upper factor. For example, the global weight C11 sub-criterion can be calculated as . Table 12 indicates that Leadership responsibilities and supports (C11) is ranked the first, Manager facilitation of continuous improvement (C43) is the second rank and among the 32 sub-criterion Comparison of indicators (C82) and Benchmarking (C83) were ranked the last with the smallest global weight of 0.003 .

The results confirm that continuous support from the top management and their effort towards never-ending continuous quality improvement leads to better overall performance in TQM practices. Thus, top-management commitment is a driving force for the successful implementation of TQM practice in supporting industries in Vietnam. Also, the quality department role is highlighted. Since it is to promote and build quality within all departments of the organization.

\section{Conclusions}

The objective of this study is to prioritize the TQM factors based on fuzzy AHP method in Vietnamese supporting industries. Through an in-depth literature review, eight criteria were identified. These criteria were then divided to 32 subcriteria. A case application shows the applicability of this approach to identifying the relative importance TQM factors. Thanks to the advantage of fuzzy AHP, this proposed approach can provide an effective, objective and scientific measure to evaluate the expert opinion. The research findings show that among the eight criteria, Management commitment (C1) is the most important factor in TQM practices. Regarding the relative importance of the sub-criteria, it is shown that the three most important sub-criteria are Leadership responsibilities and supports (C11), Manager facilitation of continuous improvement (C43) and Degree of participation by major department heads in the quality improvement process (C12). The findings are consistent with previous studies related to evaluating and ranking CSFs of TQM implementation. The results may also be helpful for the organizational executives and quality engineers to successfully deploy TQM and focus on the development. One limitation of the study is the sample size is relative small, only 18 respondents. In addition, some of the factors can be considered for extensive study. 
Table 4: The computed global weights of criteria and sub-criteria

\begin{tabular}{|c|c|c|c|c|c|c|}
\hline Criterion & $\begin{array}{c}\text { Local } \\
\text { weight }\end{array}$ & $\begin{array}{c}\text { Criterion } \\
\text { rank }\end{array}$ & Sub-criterion & $\begin{array}{c}\text { Local } \\
\text { weight }\end{array}$ & $\begin{array}{l}\text { Global } \\
\text { weight }\end{array}$ & $\begin{array}{c}\text { Sub-criterion } \\
\text { rank }\end{array}$ \\
\hline \multirow{4}{*}{ Management commitment (C1) } & \multirow{4}{*}{0.389} & \multirow{4}{*}{1} & C11 & 0.559 & 0.217 & 1 \\
\hline & & & C12 & 0.211 & 0.082 & 3 \\
\hline & & & $\mathrm{C} 13$ & 0.115 & 0.045 & 7 \\
\hline & & & $\mathrm{C} 14$ & 0.115 & 0.045 & 7 \\
\hline \multirow{5}{*}{ Role of the quality department (C2) } & \multirow{5}{*}{0.2} & \multirow{5}{*}{2} & C21 & 0.362 & 0.072 & 4 \\
\hline & & & $\mathrm{C} 22$ & 0.234 & 0.047 & 6 \\
\hline & & & C23 & 0.211 & 0.042 & 9 \\
\hline & & & C24 & 0.136 & 0.027 & 12 \\
\hline & & & $\mathrm{C} 25$ & 0.057 & 0.011 & 20 \\
\hline \multirow{4}{*}{ Training and education (C3) } & \multirow{4}{*}{0.065} & \multirow{4}{*}{5} & C31 & 0.482 & 0.031 & 10 \\
\hline & & & C32 & 0.075 & 0.005 & 26 \\
\hline & & & C33 & 0.358 & 0.023 & 14 \\
\hline & & & C34 & 0.085 & 0.006 & 25 \\
\hline \multirow{4}{*}{ Continuous improvement (C4) } & \multirow{4}{*}{0.144} & \multirow{4}{*}{3} & C41 & 0.175 & 0.025 & 13 \\
\hline & & & C42 & 0.051 & 0.007 & 22 \\
\hline & & & C43 & 0.649 & 0.093 & 2 \\
\hline & & & C44 & 0.125 & 0.018 & 16 \\
\hline \multirow{5}{*}{ Quality policies (C5) } & \multirow{5}{*}{0.046} & \multirow{5}{*}{6} & C51 & 0.469 & 0.022 & 15 \\
\hline & & & C52 & 0.255 & 0.012 & 19 \\
\hline & & & C53 & 0.148 & 0.007 & 23 \\
\hline & & & C54 & 0.063 & 0.003 & 32 \\
\hline & & & C55 & 0.065 & 0.003 & 29 \\
\hline \multirow{3}{*}{ Quality data and reporting (C6) } & \multirow{3}{*}{0.107} & \multirow{3}{*}{4} & C61 & 0.637 & 0.068 & 5 \\
\hline & & & C62 & 0.258 & 0.028 & 11 \\
\hline & & & C63 & 0.105 & 0.011 & 21 \\
\hline \multirow{3}{*}{ Communication to improve quality (C7) } & \multirow{3}{*}{0.024} & \multirow{3}{*}{8} & C71 & 0.2 & 0.005 & 27 \\
\hline & & & $\mathrm{C} 72$ & 0.2 & 0.005 & 27 \\
\hline & & & C73 & 0.6 & 0.014 & 17 \\
\hline \multirow{4}{*}{ Customer satisfaction orientation (C8) } & \multirow{4}{*}{0.025} & \multirow{4}{*}{7} & C81 & 0.528 & 0.013 & 18 \\
\hline & & & C82 & 0.118 & 0.003 & 30 \\
\hline & & & $\mathrm{C} 83$ & 0.118 & 0.003 & 30 \\
\hline & & & $\mathrm{C} 84$ & 0.236 & 0.006 & 24 \\
\hline
\end{tabular}

\section{References}

Antony, J., Leung, K., Knowles, G., \& Gosh, S. (2002). Critical success factors of TQM implementation in Hong Kong industries. International Journal of Quality and Reliability Management, 19(5), 551-566.
Aquilani, B., Silvestri, C., Ruggieri, A., \& Gatti, C. (2017). A systematic literature review on total quality management critical succes factors and the identification of new avenues of research. The TQMJournal, 29(1), 184-213. 
Baidoun, S. (2003). An empirical study of critical factors of TQM in Palestinian organizations. Logistics Information Management, 16(2), 156-171.

Black, S. A., \& Porter, L. J. (1996). Identification of the Critical Factors of TQM. Decision Sciences, 27(1), 1-21.

Buckley, J. J. (1985). Fuzzy hierarchical analysis. Fuzzy Sets and Systems, 17(1985), 233-247.

Buckley, James J., Feuring, T., \& Hayashi, Y. (2001). Fuzzy hierarchical analysis revisited. European Journal of Operational Research, 129(1), 48-64.

Büyüközkan, G., \& Feyziog̃lu, O. (2004). A fuzzy-logic-based decision-making approach for new product development. International Journal of Production Economics, 90(1), 27-45. https://doi.org/10.1016/S0925-5273(02)00330-4.

Chang, D.-Y. (1992). Extent analysis and synthetic decision, optimization techniques and applications (vol. 1). Singapore: World Scientific.

Chang, D. Y. (1996). Applications of the extent analysis method on fuzzy AHP. European Journal of Operational Research, 95(1996), 649-655. https://doi.org/10.1016/03772217(95)00300-2.

Chen, C. F., \& Lee, C. L. (2011). Determining the attribute weightsof professional conference organizer selection: An application of the fuzzy AHP approach. Tourism Economics, 17(5), 1-11. https://doi.org/10.5367/te.2011.0075.

Chin, K. S., Pun, K. F., Xu, Y., \& Chan, J. S. F. (2002). An AHP based study of critical factors for TQM implementation in Shanghai manufacturing industries. Technovation, 22(11), 707-715. https://doi.org/10.1016/S0166-4972(01)00065-7.

Chowdhury, M., Paul, H., \& Das, A. (2007). The impact of top management commitment on total quality management practice: An exploratory study in the Thai garment industry. Global Journal of Flexible Systems Management, 8 (2007), 17 29. https://doi.org/10.1007/BF03396517.

Das, A., Paul, H., \& Swierczek, F. W. (2008). Developing and validating total quality management (TQM) constructs in the context of Thailand's manufacturing industry. Benchmarking: An International Journal, 15(1), 52-72. https://doi. org/10.1108/14635770810854344.

Forman, E., \& Peniwati, K. (1998). Aggregating individual judgments and priorities with the Analytic Hierarchy Process. European Journal of Operational Research, 108(1), 165-169. https://doi.org/10.1016/S0377-2217(97)00244-0.

Hackman, J. R., \& Wageman, R. (1995). Total Quality Management: Empirical, Conceptual, and Practical Issues. Administrative Science Quarterly, 40(2), 309-342.https://doi. org/10.2307/2393640.

Hietschold, N., Reinhardt, R., \& Gurtner, S. (2014). Measuring critical success factors of TQM implementation successfully-a systematic literature review. International Journal of Production Research, 52(21), 6254-6272.
Jayaram, J., Ahire, S. L., \& Dreyfus, P. (2010). Contingency relationships of firm size, TQM duration, unionization, and industry context on TQM implementation-A focus on total effects. Journal of Operations Management, 28(4), 345-356.

Joseph, I. N., Rajendran, C., \& Kamalanabhan, T. J. (1999). An instrument for measuring total quality management implementation inmanufacturing based business units in India. International Journal of Production Research, 37(10), 22012215. https://doi.org/10.1080/002075499190725.

Kahraman, C., Ertay, T., \& Büyüközkan, G. (2006). A fuzzy optimization model for QFD planning process using analytic network approach. European Journal of Operational Research, 171(2), 390-411. https://doi.org/10.1016/j.ejor.2004.09.016

Kanji, G., \& Asher, M. (1993). Education and training for total quality management. Total Quality Management, 4(4), 77-84.

Kassicieh, S. K., \& Yourstone, S. A. (1998). Training, performance evaluation, rewards, and TQM implementation success. Journal of Quality Management, 3(1), 25-38.

Khanam, S., Siddiqui, J., \& Talib, F. (2015). Prioritising the TQM Enablers and IT Resources in the ICT Industry: An AHP Approach. International Journal of Social, Behavioral, Educational, Economic and Management Engineering, 9(5), 1683- 1690.

Kim, B. S., \& Kim, B. Y. (2020). The Effect of Selection Factors of Marine Transportation Service on Transaction Continuity. Journal of Asian Finance, Economics and Business, 7(1), 217 228. https://doi.org/10.13106/jafeb.2020.vol7.no1.217

Koilakuntla, M., Patyal, V. S., Modgil, S., \& Ekkuluri, P. (2012). A Research Study on Estimation of TQM 'Factors Ratings' Through Analytical Hierarchy Process. Procedia Economics and Finance, 3(2012), 55-61.

Lee, E. S., \& Li, R. J. (1988). Comparison of fuzzy numbers based on the probability measure of fuzzy events. Computers and Mathematics with Applications, 15(10), 887-896. https://doi. org/10.1016/0898-1221(88)90124-1.

Lewis, W. G., Pun, K. F., \& Lalla, T. R. M. (2005). An AHP-based study of TQM benefits in ISO 9001 certified SMEs in Trinidad and Tobago. TQM Magazine, 17(6), 558-572. https://doi. org/10.1108/09544780510627651.

Mehra, S., Huffman, J. M., Austin, S. F., \& Sirias, D. (2001). TQM as a management strategy for the next millennia. International Journal of Operations and Production Management, 21(5/6), 855-876. https://doi.org/10.1108/01443570110390534.

Miller, G. A. (1956). The magical number seven, plus or minus two: some limits on our capacity for processing information. Psychological Review, 63(2), 81-97. https://doi.org/10.1037/ h0043158.

Nair, A. (2006). Meta- analysis of the relationship between quality management practices and firm performance-implications for quality management theory development. Journal of Operations Management, 24(2006) 948-975. https://doi. org/10.1016/j.jom.2005.11.005. 
Oakland, J. (2011). Leadership and policy deployment: The backbone of TQM. Total Quality Management and Business Excellence, 22(5), 517-534. https://doi.org/10.1080/14783363.2011.579407.

Pham, V. Q., Nguyen, B. K. Q., Tu, B. V., Pham, H. T. T., \& Le, T. Q. (2019). Critical Success Factors of Project Management: The Case of Construction Related Projects in Vietnam. Journal of Asian Finance, Economics and Business, 6(2), 223-230. https://doi.org/10.13106/jafeb.2019.vol6.no2.223

Rahman, M. M., \& Saima, F. N. (2018). Efficiency of board composition on firm performance: Empirical evidence from listed manufacturing firms of Bangladesh. Journal of Asian Finance, Economics and Business, 5(2), 53-61. https://doi. org/10.13106/jafeb.2018.vol5.no2.53

Rao, S. S., Solis, L. E., \& Raghunathan, T. S. (1999). A framework for international quality management research: Development and validation of a measurement instrument. Total Quality Management, 10(7), 1047 -1075. https://doi. org/10.1080/0954412997226.

Saaty, T. L. (1980). The Analytic Hierarchy Process: Planning, priority setting, resource allocation. New York, USA: McGraw-Hill.

Salaheldin, S.I.(2009).CriticalsuccessfactorsforTQMimplementation and their impact on performance of SMEs. International Journal of Productivity and Performance Management, 58(3), 215-237. https://doi.org/10.1108/17410400910938832.

Salgado, E. G., da Silva, E. R. S., da Silva, C. E. S., \& Pereira Mello, C. H. (2015). An analytic hierarchy process analysis for small and medium sized enterprises: prioritizing the practices of total quality management in Brazil. International Journal for Quality Research, 9(2), 185-196.

Saraph, J. V, Benson, P. G., \& Schroeder, R. G. (1989). An instrument for measuring the critical factors of quality management. Decision Sciences, 20(4), 810-829.
Sarathy, P. S. (2013). TQM practice in real-estate industry using AHP. Quality and Quantity, 47(4), 2049-2063. https://doi. org/10.1007/s11135-011-9641-8.

Talib, F., Rahman, Z., \& Qureshi, M. N. (2011). Prioritising the practices of total quality management: An analytic hierarchy process analysis for the service industries. Total Quality Management and Business Excellence, 22(12), 1331-1351. https://doi.org/10.1080/14783363.2011.625192

Tseng, M.-L., Lin, Y.-H., Chiu, A. S. F., \& Chen, C. Y. (2008). Fuzzy AHP approach to TQM strategy evaluation. Industrial Engineering \& Management Systems, 7(1), 34-43.

Ulle, R. S., \& Kumar, A. N. S. (2015). Key Performance Indicators of TQM-An Analysis by using Analytical Hierarchy Process. The International Journal of Business \& Management, 3(8), 155-159.

Van Laarhoven, P. J. M., \& Pedrycz, W. (1983). A fuzzy extension of Saaty's priority theory. Fuzzy Sets and Systems, 11(1-3), 229-241. https://doi.org/10.1016/S0165-0114(83)80082-7.

Wang, G., \& Li, X. (2010). Research on total quality management based on AHP. 2010 Second Pacific-Asia Conference on Circuits, Communications and System (pp 245-248). Beijing, China, August 1-2, Beijing: Piscataway, NJ IEEE.

Welikala, D., \& Sohal, A. S. (2008). Total Quality Management and employees' involvement: A case study of an Australian organisation. Total Quality Management and Business Excellence, 19(6), 627-642. https://doi. org/10.1080/14783360802024440

Zadeh, L. A. (1975). The concept of a linguistic variable and its application to approximate reasoning-I. Information Sciences, 8(3), 199-249. https://doi.org/10.1016/0020-0255(75)90036-5 